\title{
Prinsip-prinsip biomekanika kualitatif: upaya menjembatani teori dan aplikasi dalam sport science
}

\author{
Hysa Ardiyanto ${ }^{1 *}$, Widiyanto $^{2}$ \\ ${ }^{1}$ Program Studi IImu Keolahragaan Pascasarjana Universitas Negeri Yogyakarta; \\ ${ }^{2}$ Pusat Studi Olahraga Universitas Negeri Yogyakarta; \\ "Corresponding author: hysaardiy.2017@student.uny.ac.id; hysaardiyanto@gmail.com
}

This article has been submitted for publication in Media IImu Keolahragaan Indonesia. Please carefully note that subsequent versions of this manuscript may have different content.

\begin{abstract}
Abstrak
Asian Games 2018 dinilai sebagai pendorong kebangkitan olahraga nasional yang diiringi dengan penguatan peran sport science. Sebagai salah satu area sport science, biomekanika menyediakan analisis gerak yang berguna untuk meningkatkan performa atlet. Masalahnya, prinsip dan hukum mekanika Newtonian yang umum digunakan dinilai sulit karena counterintuitive dan kurang memberikan analisis yang bermakna. Pada saat yang bersamaan, kesenjangan antara teori dan aplikasi pada sport science masih terjadi. Merespon persoalan tersebut, beberapa ahli berupaya mengembangkan seperangkat prinsip-prinsip umum untuk aplikasi biomekanika kualitatif. Dalam tulisan ini disajikan tinjauan literatur yang membahas prinsip-prinsip biomekanika kualitatif sebagai sebuah upaya menjembatani antara teori dan aplikasi dalam sport science, terutama pada kepelatihan olahraga.
\end{abstract}

Keywords: Asian Games 2018, analisis kualitatif, biomekanika olahraga, sport science

\begin{abstract}
The Asian Games 2018 has been considered as booster in attempts to promote the resurgence of national sport, along with the growing attention towards sport science. As one of the area of sport science, biomechanics provides movement analysis to enhance athletes' performance. Biomechanics principles and laws of Newtonian mechanics, however, are counterintuitive to a lot of people. Some of them often produced less meaningful results. At the same time the theory-practice gap, unfurtunately, still remains. Several biomechanics scholars have developed a set of general principles to facilitate the qualitative application of biomechanics. Those principles used terminology that bridges the gap between theory and coaching application.
\end{abstract}

Keywords: Asian Games 2018, qualitative analysis, sport biomechanic; sport science

\section{Pendahuluan}

Asian Games 2018 dinilai berhasil oleh berbagai kalangan, baik dalam segi penyelenggaraan maupun prestasi. Dari prestasi, perolehan medali kontingan Indonesia bahkan memecahkan rekor sepanjang partisipasi dalam Asian Games. Kesuksesan ini kemudian disebut-sebut sebagai momentum kebangkitan olahraga nasional dan kebangkitan prestasi olahraga di tingkat internasional (Irianto, 2018). Momentum tersebut segera disambut oleh dunia sport science di Indonesia, salah satunya oleh Indonesia Society of Exercise \& Sport Science (ISESS) dengan seminar internasional bertema "Kebangkitan Olahraga Indonesia Pasca Asian Games dan Asian Para Games 2018". Gagasan yang 
berkembang seiring dengan kebangkitan olahraga nasional adalah semakin pentingnya peran sport science dalam pembinaan prestasi.

Salah satu disiplin ilmu yang diakui sebagai penopang sport science adalah biomekanika olahraga. Pada dasarnya biomekanika olahraga telah diakui sebagai salah satu subdisiplin ilmu yang sudah mapan (established subdisciplines) dalam struktur ilmu keolahragaan. Bersama dengan kedokteran olahraga, psikologi olahraga, pedagogi olahraga, sosiologi olahraga, sejarah olahraga, dan filsafat olahraga, biomekanika olahraga termasuk subdisiplin ilmu dalam seven field theory model (Haag, Grupe, \& Kirsch, 1992). Keberadaan biomekanika dianggap sebagai salah satu disiplin ilmu yang berkontribusi dalam kajian interdisiplin untuk menginvestigasi performa olahraga tingkat elit (Buekers et al., 2016). Sementara itu dari sumber daya manusia, ahli biomekanika disebut sebagai tenaga keolahragaan yang diakui oleh Undang Undang No. 3 Tahun 2005 tentang Sistem Keolahragaan Nasional (Pemerintah Republik Indonesia, 2005). Hal ini menunjukkan posisi biomekanika olahraga baik secara teori maupun aplikasi bidang ilmu keolahragaan.

Dalam mendukung kebangkitan olahraga nasional melalui peningkatan pemahaman sport science, pengetahuan prinsip-prinsip biomekanika olahraga menjadi hal yang penting bagi para pelatih. Penelitian-penelitian aplikasi biomekanika olahraga di Indonesia telah dilakukan, antara lain, dengan menggunakan pendekatan mekanika (Adina, Saichudin, \& Kinanti, 2017), pendekatan mekanika yang dipadukan dengan anatomi (Iskandar, 2013; Wijaya, 2017), analisis biomekanika melalui survei tes (Anam \& Hidayah, 2014), survei dan analisis program komputer (Rismayanthi \& Alim, 2011) serta analisis biomekanika dengan menekankan aspek umpan balik (Arifin, 2014). Melihat beberapa hasil penelitian tersebut, kajian biomekanika olahraga banyak diwarnai oleh penelitian-penelitian yang menggunakan pendekatan mekanika kuantitatif.

Pendekatan mekanika kuantitatif dinilai mampu memberikan data yang kaya dengan validitas dan reliabilitas yang tinggi, namun pendekatan ini juga dinilai berpotensi kurang memberikan makna bagi pelatih atau atlet. Kelemahan ini yang disebut sebagai krisis kepercayaan diri dalam hasil penelitian biomekanika olahraga (Knudson, 2009, 2017). Pendekatan mekanika Newtonian diakui dapat membantu memahami beberapa aspek dalam gerak manusia. Namun hukum-hukum biomekanika di dalamnya dinilai sulit dipahami berdasarkan intuisi (counterintuitive) bagi banyak pelaku olahraga termasuk pelatih olahraga, dan bahkan mahasiswa yang mengambil kuliah biomekanika olahraga (Knudson, 2007b). Selain itu muncul pertanyaan apakah data-data kuantitatif yang banyak tersebut relevan untuk mengetahui pola gerak yang diharapkan (Knudson, 2007b). Pertanyaan senada yang mencuat adalah berkaitan dengan variabilitas atau keragaman gerak (movement variability) sebagai sesuatu yang fungsional dalam penelitian biomekanika olahraga (Bartlett, Wheat, \& Robins, 2007). Munculnya pertanyaan tersebut mengindikasikan masih adanya celah antara teori dan aplikasi dalam biomekanika olahraga.

Harus diakui, kesenjangan antara teori dan praktik dalam kepelatihan (coaching) masih terjadi. Kesenjangan ini tidak terlepas dari kontribusi kedua pihak baik akademisi maupun praktisi. Para akademisi dinilai melihat pengembangan teori lebih penting daripada peningkatan praktis di lapangan. Sebaliknya, terdapat praktisi dan pelatih yang cenderung bersikap anti-intelektual dengan menolak pengembangan teori yang dinilai tidak relevan dengan aktivitas latihan keseharian (Jones, 2011, p.7). Kesenjangan ini menciptakan ironi di mana sport science yang merupakan ilmu terapan justru terkendala dalam aplikasinya sehingga masih ditemui adanya hasil riset yang tidak cukup sukses ketika diaplikasikan di lapangan (Kristiyanto, 2017). Penyusunan prinsip-prinsip umum biomekanika kualitatif dapat dilihat sebagai upaya dari pihak akademisi untuk menjembatani kesenjangan tersebut.

Para ilmuwan biomekanika olahraga sendiri telah lama memiliki ketertarikan untuk mengembangkan prinsip-prinsip biomekanika yang dapat memfasilitasi aplikasi kualitatif (Knudson, 2007b). Gagasan tersebut semakin mendapat perhatian sering dengan pemanfaatan analisis biomekanika kualitatif di lapangan (lihat misalnya Bartlett, 2007; McGinnis, 2013). Analisis biomekanika olahraga kemudian banyak menggunakan pendekatan kualitatif. Dengan kata lain, 
prinsip-prinsip biomekanika kualitatif berpotensi membantu pemahaman secara teori ketika dihadapkan pada kondisi di lapangan dan berperan menjembatani teori dan aplikasi sport science.

Berdasarkan pemikiran-pemikiran tersebut, tulisan ini membahas prinsip-prinsip biomekanika kualitatif sebagai upaya menjembatani antara teori dan aplikasi dalam sport science, khususnya biomekanika olahraga. Pembahasan dimulai dengan pengantar mengenai perbedaan antara pendekatan kuantitatif dan kualitatif dalam biomekanika olahraga. Selanjutnya memunculkan 'pola gerak' sebagai esensi analisis biomekanika dengan menunjukkan adanya pergeseran definisi dan cara pandang terhadap biomekanika olahraga ke arah kualitatif. Pada bagian berikutnya dibahas latar belakang dari upaya penyusunan prinsip-prinsip biomekanika kualitatif, ringkasan konsep mengenai prinsip-prinsip umum oleh Duane Knudson, salah seorang pakar biomekanika olahraga, yang dipandang mampu menjangkau penerapan biomekanika secara kualitatif, dan bagaimana gagasan tersebut dipandang sebagai upaya menerapkan sport science.

\section{Pembahasan}

\subsection{Pendekatan kuantitatif dan kualitatif dalam analisis biomekanika olahraga}

Dalam melakukan analisis biomekanika pada performa olahraga, terdapat dua jenis pendekatan yang biasa dilakukan, yaitu analisis kuantitatif dan analisis kualitatif. Pada pendekatan kuantitatif, gerakan dianalisis menggunakan seperangkat alat dengan kalkulasi tertentu seperti analisis gerak berbasis gambar menggunakan video, sistem pendeteksi gerak otomatis, elektromyografi, atau papan pangukur gaya/tekanan. Data-data kuantitatif kemudian dianalisis menggunakan statistik dan simulasi komputer. Sementara itu analisis kualitatif mengandalkan observasi oleh pelatih atau analis gerak baik secara langsung ataupun melalui rekaman video. Jika analisis kuantitatif pada lebih banyak dilakukan oleh peneliti untuk kepentingan riset, analisis kualitatif lebih umum dilakukan di lapangan oleh pelatih, fisioterapis, atau juri olahraga artistik. Secara umum perbedaan antara analisis kualitatif dan kuantitatif adalah analisis kualitatif mendeskripsikan secara non-numerik dengan melihat gerakan sebagai pola, sedangkan analisis kuantitatif mendeskripsikan gerakan secara numerik (Bartlett, 2007, p.36-37).

Perbedaan-perbedaan pada kedua pendekatan tersebut dapat mengarah pada ekstremitas dalam memandang aplikasi biomekanika olahraga (Knudson, 2007b). Pada satu sisi ada pendekatan kualitatif berdasarkan instant observation, sementara di sisi lain terdapat pendekatan secara kuantitatif dengan pemodelan komputer atau simulasi. Analisis kuantitatif sering kali tampak lebih objektif karena adanya data-data yang dapat dilihat secara empirik. Pada analisis kuantitatif terkandung banyak sekali data dan informasi. Namun pertanyaannya kemudian, apakah semua data dan informasi tersebut relevan untuk mengetahui pola gerak yang diharapkan. Dari segi eksistensi, analisis kualitatif lebih mengakar kuat dalam pendekatan yang terstruktur dan multidisiplin dibandingkan analisis kuantitatif (Bartlett, 2007, p.38).

Pendekatan kualitiatif terlihat mengalami perkembangan yang signifikan. Pada aplikasi di lapangan, analisis kualititif lebih berpotensi untuk dapat dikembangkan oleh para pelatih, guru, dan instruktur di tingkat grassroots daripada pendekatan kuantitatif. Menurut Bartlett (2007, p. 39) hal tersebut memungkinkan karena beberapa keunggulan analisis kualitatif, seperti: (1) tidak membutuhkan peralatan yang mahal, (2) berbasis pada lapangan, bukan laboratorium, sehingga memiliki tingkat validitas ekologi yang lebih baik, (3) jika dikerjakan dengan baik, analisis kualitatif akan tampil sistematis karena berfokus pada pola bukan kuantitas data, (4) pola gerak lebih "bisa berbicara" dibandingkan angka-angka (a picture is worth a thousand words), serta (5) lebih ramah bagi para pelatih dan tidak mengintimidasi karena kompleksitas datanya. Namun demikian, pendekatan kualitatif kadang berhadapan dengan persoalan validitas dan reliabilitas yang diragukan dan sulit ditakar karena adanya bias subjektivitas analis. Hal ini dinilai sebagai kelemahan yang muncul akibat kurangnya data numerik, dan tingkat pengetahuan analis tentang gerak. 


\subsection{Analisis pola gerak tubuh sebagai esensi biomekanika olahraga}

Biomekanika dapat diartikan sebagai ilmu yang mempelajari gaya dan efeknya pada sistem hidup atau ilmu tentang struktur dan fungsi sistem biologi dalam sudut pandang metode mekanika (McGinnis, 2013, p.3). Mekanika sendiri merupakan cabang dari fisika yang menaruh perhatian pada gerak dan bagaimana gaya menyebabkan gerak. Tidak mengherankan jika prinsip mekanika juga berlaku pada makhluk hidup di mana gerak merupakan ciri-ciri utamanya. Biomekanika dengan demikian menyediakan kerangka konseptual dan matematis yang dibutuhkan dalam memahami bagaimana suatu sistem biologi bergerak (Knudson, 2007a, p.3). Penekanan pada kata mekanika juga mengandung konsekuensi analisis biomekanika berhubungan erat dengan konsep dasar dan standar pengukuran dalam mekanika seperti panjang (dalam satuan meter), waktu (detik), dan massa (kilogram) (McGinnis, 2013, p.15).

Dari pengertian di atas dapat dilihat jika pembentukan kajian biomekanika olahraga sangat bernuansa kuantitatif dengan penekanan pada hukum-hukum mekanika. Pada awal perkembangannya, studi biomekanika olahraga memang berasal dari peneliti/penulis berlatar belakang matematika, teknik atau fisika. Buku-buku teks biomekanika olahraga terdahulu menekankan pada aspek mekanika dan penekanan yang kuat pada analisis kuantitatif. Hal ini yang terus berlanjut seiring dengan perkembangan analisis biomekanika pada olahraga. Namun jika ditarik pada fungsi biomekanika olahraga, penggunaan definisi biomekanika yang berorientasi pada mekanika ini dinilai sering kurang memberikan pemahaman yang bermakna.

Sesuai dengan fungsi dasarnya, biomekanika olahraga membantu meningkatkan performa dan mengurangi risiko cedera atlet. Meningkatkan performa artinya meningkatkan efektivitas gerak. Gerak yang efektif melibatkan faktor anatomi, kapasitas fisiologi, keterampilan neuromuscular dan kemampuan psikologis/kognitif. Analisis biomekanika lebih berpengaruh pada jenis olahraga yang didominasi kemampuan teknik, dibandingkan olahraga yang mengandalkan keunggulan struktur fisik atau kapasitas fisiologi. Lari marathon adalah contoh yang bagus dalam hal ini. Faktor kemampuan fisiologis dan psikologis dalam lari matahon lebih dominan jika dibandingkan keterampilan teknik gerak, sehingga perbaikan teknik atau peningkatan efektivitas gerak hanya menyumbangkan sedikit perbaikan performa (Knudson, 2007a, p.5-7). Berbeda dengan lari sprint 100 meter, di mana analisis biomekanika olahraga memiliki porsi yang lebih besar terhadap efektivitas gerak pelari.

Sementara itu dalam hal pencegahan cedera dan, para peneliti di bidang olahraga kesehatan telah membangun tradisi yang kuat dalam mempelajari data cedera dan berusaha menjelaskan potensi penyebab cedera. Riset biomekanika olahraga membantu dalam pencegahan cedera dengan menyediakan informasi yang berhubungan dengan prinsip mekanika seperti besar tekanan, nilai gaya yang berpotensi menyebabkan cedera (Knudson, 2007a, p.9). Cabang olahraga senam merupakan contoh yang baik bagaimana biomekanika olahraga diterapkan. Pada gerakan-gerakan senam, berlaku hukum mekanika yang kompleks. Efek dari gaya yang terus-menerus merupakan penyebab overuse injury yang sering dialami para atlet. Teknik gerak, loncat atau mendarat yang tepat, dengan analisis biomekanika olahraga, membantu mengurangi resiko cedera tersebut (McGinnis, 2013, p.10).

Kebutuhan praktis di lapangan telah mengubah cara pandang terhadap biomekanika olahraga. Para sarjana yang lulus dengan kompetensi biomekanika akan lebih memilih bekerja sebagai movement analyst atau performance analyst di organisasi olahraga dibandingkan melanjutkan di bidang penelitian. Mereka lebih banyak mengerjakan analisis kualitatif gerak, dibandingkan kuantitatif. Inilah yang membuat Bartlett (2007, p.xvii) mengajukan definisi yang "tidak konsisten" terhadap biomekanika olahraga, dari pernyataan sebelumnya, "sports biomechanic uses the scientific methods of mechanics to study the effect of various forces on the sports performer" menjadi "the study and analysis of human movement patterns in sport". Pengertian biomekanika olahraga yang menekankan pada penggunaan metode ilmiah dalam mekanika untuk mempelajari efek dari berbagai gaya pada atlet bergeser menjadi definisi dalam kalimat yang lebih sederhana yaitu kajian dan analisis pola gerak manusia dalam olahraga. 
Perubahan lain yang signifikan dalam perkembangan analisis biomekanika olahraga adalah pada pergeseran penggunaan istilah untuk menyebut ahli biomekanika, dari sports biomechanist ke movement analyst yang merefleksikan perubahan dari analisis kuantitatif ke kualitatif. Perubahan ini tidak serta merta menghilangkan analisis secara kuantitatif, namun untuk menjadi seorang movement analyst kuantitatif yang baik tidak bisa tanpa terlebih dahulu menjadi seorang movement analyst kualitatif (Bartlett, 2007, p.1-2). Untuk padanan dalam Bahasa Indonesia, movement analyst mungkin dapat diterjemahkan sebagai analis gerak (olahraga). Analisis pola gerak tubuh manusia dalam aktivitas olahraga inilah yang kemudian dapat dianggap sebagai esensi biomekanika olahraga.

\subsection{Upaya menyusun prinsip-prinsip umum biomekanika kualitatif}

Konsep-konsep dalam biomekanika olahraga diakui banyak diambil dari mekanika Newtonian.

Pada dasarnya biomekanika berakar dari ilmu alam yang cenderung positivistik-kuantitatif. Penelitian berbasis mekanika kuantitatif mungkin memberi data yang kaya. Namun apakah datadata tersebut benar-benar bermakna dalam aplikasi di lapangan. Beberapa pihak pun berargumen jika mekanika Newtonian dan penelitian biomekanika mampu memberikan pengetahuan yang bermakna tentang bagaimana meningkatkan kualitas gerak manusia (Knudson, 2007b). Pertanyaannya kemudian adalah, kata 'bagaimana' atau cara yang dimaksud dalam pernyataan tersebut berada dalam konteks seperti apa? Apakah aplikasi biomekanika olahraga di lapangan, gimnasium atau laboratorium yang masing-masing realitasnya berbeda. Lalu apa saja yang dapat dipertimbangkan sebagai pengetahuan biomekanika oleh pelatih? Isu lainnya, bagaimana pengalaman profesional pelatih berhadapan dengan riset biomekanika? Beberapa pertanyaan tersebut agaknya mendasari pandangan untuk menunjukkan legitimasi atas upaya mengangkat pembahasan prinsip-prinsip biomekanika kualitatif dalam menganalisis performa olahraga.

Pembahasan prinsip-prinsip biomekanika kualitatif dinilai penting karena, pada kenyataannya, praktik analisis biomekanika kualitatif jamak dilakukan oleh para pelatih olahraga di lapangan. Analisis kualitatif bahkan dinilai sebagai metode utama untuk meningkatkan gerak manusia yang dilakukan oleh para profesional di bidang kinesiologi terhadap para kliennya (Knudson \& Morrison, 2002, p.1). Analisis gerak dalam cabang olahraga menggunakan prinsip-prinsip biomekanika secara deskriptif eksploratif yang mendekati analisis kualitatif berpotensi memberikan evaluasi dan umpan balik terhadap performa atlet (lihat misalnya Widiyanto \& Hariono, 2014). Selain itu, hasil analisis biomekanika kualitatif berpotensi digunakan untuk menetapkan key coaching/teaching point pada suatu gerakan dalam olahraga (contohnya penelitian Tighe \& Kenny, 2015). Tambahan lagi, meskipun tidak secara langsung berkaitan dengan prinsip-prinsip biomekanika kualitatif, studi pada pencegahan cedera (khususnya overuse injury) dengan menggunakan pendekatan kualitatif dapat membuka jalan bagi pemahaman secara holistik dan melibatkan kajian interdisiplin (van Wilgen \& Verhagen, 2012). Temuan ini selaras dengan pendangan Knudson (2005) yang menilai riset intersidiplin sebagai suatu area yang harus ditingkatkan dalam membahas kesenjangan antara teori dan praktik dalam kinesiologi di mana terdapat pembahasan biomekanika olahraga.

Pembahasan prinsip-prinsip biomekanika kualitatif juga didorong oleh perubahan yang terjadi dalam biomekanika olahraga, terutama kebutuhan praktis di lapangan yang ikut mengubah cara pandang terhadap biomekanika olahraga. Para pelatih, guru pendidikan jasmani, dan analis biomekanika di lapangan lebih banyak mengerjakan analisis kualitatif gerak, dibandingkan analisis kuantitatif. Perubahan ini menurut Bartlett (2007, p.xvii), seperti telah disampaikan sebelumnya, berdampak pada perubahan istilah dari sports biomechanist menjadi movement analyst, suatu perubahan dari istilah yang bernuansa kuantitatif ke kualitatif.

Analisis kualitatif merupakan salah satu aktivitas profesional yang paling penting yang perlu dikuasai oleh para pelatih. Analisis kualitatif dapat didefinisikan sebagai observasi sistematik dan penilaian introspektif atas kualitas gerak manusia dengan tujuan memberikan intervensi yang paling sesuai untuk meningkatkan performa (Knudson \& Morrison, 2002, p.4). Penjelasan ini dinilai lebih 
bermakna bagi aplikasi di lapangan tanpa kehilangan landasar ilmiah yang memadai. Penelitian kuantitatif pada atlet elit biasanya juga diimplementasikan dengan kualitatif sebagai bahan untuk memberikan umpan balik kepada atlet. Jika ditarik pada aplikasi di lapangan, beberapa penelitian biomekanika olahraga dengan pendekatan mekanika dan analisis data dilengkapi juga dengan kisikisi yang bersifat kualitatif (misalnya pada Kurniawan, 2015). Selain digunakan dalam olahraga prestasi, prinsip-prinsip biomekanika kualitatif juga sering dijumpai pada aktivitas olahraga dalam konteks pendidikan.

Upaya menyusun prinsip-prinsip biomekanika kualitatif merupakan respon dari masalahmasalah yang disebut sebagai "biomechanical application chaos". Di antara komunitas pelatih dengan para ahli biomekanika sering terjadi kebingungan mengenai apa yang dimaksud dengan "aplikasi" yang bermakna dalam biomekanika olahraga. Hal ini dalam pandangan Knudson (2007b) disebabkan oleh: pertama, usia ilmu biomekanika olahraga yang relatif masih muda dibandingkan disiplin penyusun ilmu keolahragaan lainnya. Kondisi ini berakibat pada masih sedikitnya penelitian biomekanika sehingga sedikit pula artikel review atau metaanalisis di bidang biomekanika olahraga. Pada umumnya para pelatih kesulitan mengakses penelitian asli, sehingga review yang berwibawa (authoritative) sangat dibutuhkan untuk memahami dan mengaplikasikan biomekanika pada olahraga. Selain itu alokasi dana riset juga menjadi isu yang berkaitan erat karena biomekanika olahraga belum menjadi prioritas. Dalam kebijakan olahraga di negara berkembang misalnya, daripada untuk penelitian biomekanika, anggaran pemerintah lebih diprioritaskan untuk peningkatan gizi atlet, perbaikan sarana olahraga atau pengadaan fasilitas dasar untuk latihan. Hal ini bisa dimaklumi, apalagi penelitian biomekanika olahraga membutuhkan instrumen yang tidak murah. Akibat dari sedikitnya penelitian, berarti sedikit pula bukti ilmiah yang bisa disajikan.

Kedua, hukum-hukum mekanika Newton dianggap berlawanan dengan intuisi (counterintuitive) dan sulit dipelajari. Sebenarnya kesulitan dalam mempelajari biomekanika olahraga tidak hanya dialami kalangan umum. Mahasiswa kinesiologi atau ilmu keolahragaan yang mengambil mata kuliah biomekanika pun mengalaminya. Hambatan yang mereka hadapi mengarah pada isu tentang konsep mekanika yang kompleks (Hsieh \& Knudson, 2017; Knudson, 2013). Persepsi atas kepercayaan diri mahasiswa merupakan faktor yang dinilai paling penting dalam memahami konsep biomekanika yang paling kompleks dan sulit. Intuisi, dengan demikian, diakui berperan dalam memahami analisis biomekanika yang bermakna.

Ketiga, terminologi dalam biomekanika olahraga yang dinilai tidak konsisten. Para pelatih kadang menggunakan istilah pribadi yang berbeda dengan teori atau prinsip biomekanika olahraga. Hal ini sangat mudah ditemui, apalagi jika ditambahkan faktor perbedaan budaya dan bahasa. Untuk membedakan gerakan olahraga dalam analisis biomekanika olahraga dengan gerakan lainnya, dibutuhkan terminologi ilmiah yang memadai (Bartlett, 2007, p.3-4). Keempat, Tidak adanya konsensus atas apa yang sebenarnya dimaksud dengan "aplikasi biomekanika yang bermakna". Ini yang menjadi bagian yang secara gamblang melandasi pembahasan aplikasi kualitatif biomekanika pada olahraga. Dalam beberapa kasus, buku-buku biomekanika lebih seperti buku fisika yang menggunakan olahraga sebagai ilustrasi contoh sehingga kurang memberikan wawasan yang bermakna bagi pelatih.

Setelah memaparkan apa yang disebutnya sebagai kekacauan dalam penerapan biomekanika pada olahraga, Knudson (2007b) kemudian mengajukan sebuah tatanan prinsip umum (order from chaos) dari aplikasi biomekanika olahraga. Gagasan ini dapat dinilai sebagai salah satu upaya penting untuk membentuk suatu konsensus atas urgensi pemahaman yang lebih bermakna pada hasil analisis biomekanika olahraga. Tabel 1 menunjukkan sebuah ringkasan konsep mengenai prinsipprinsip umum yang dipandang mampu menjangkau penerapan biomekanika olahraga secara kualitatif oleh Knudson. Ringkasan ini dimaksudkan untuk merangsang diskusi lebih lanjut mengenai prinsip-prinsip yang bisa digunakan sebagai kerangka teori untuk mengajarkan dan menerapkan biomekanika kualitatif pada olahraga. 
Tabel 1. Perbandingan prinsip umum biomekanika oleh tiga ahli biomekanika olahraga. Sumber: Knudson (2007b)

\begin{tabular}{|c|c|c|}
\hline Knudson (2003) & Hudson (1995) & Norman (1975) \\
\hline \multicolumn{3}{|l|}{ Movement principles } \\
\hline Balance & Balance & Stability \\
\hline Coordination continuum & Coordination & Continuity of joint free \\
\hline Force-motion & & Combined influence of force and its \\
\hline Force - time & & application time \\
\hline Inertia & Compactness & \\
\hline Range of motion & Range of motion & Direction of force application \\
\hline \multirow[t]{2}{*}{ Segmental interaction } & Nature of segments & Summation of joint free \\
\hline & Number of segments & Summation of body segment velocities \\
\hline Projectile principles & & Production of angular momentum \\
\hline Optimal projection & Path of projection & \\
\hline \multirow[t]{3}{*}{ Spin } & Spin & $\begin{array}{l}\text { Conservation of momentum (linear \& } \\
\text { angular) }\end{array}$ \\
\hline & Speed of motion & Manipulation of weight distribution \\
\hline & Extension at release & $\begin{array}{l}\text { Manipulation of segment angular } \\
\text { momentum }\end{array}$ \\
\hline
\end{tabular}

Perbandingan yang diajukan oleh ketiga pakar biomekanika olahraga Amerika Utara pada tabel 1 menunjukkan suatu kelompok kategori dalam gerak. Di sana dapat dilihat bahwa Bob Norman mengajukan hipotesis sepuluh prinsip biomekanika olahraga yang dinilai bisa digunakan untuk memfasilitasi pembelajaran dan pelatihan. Prinsip-prinsip yang diajukannya berfokus pada penyebab kesalahan dan dinamika gerak manusia dibandingkan posisi tubuh tertentu (discrete) yang kurang bermakna. Tujuh prinsip pertama, menurutnya, dapat dijadikan pijakan awal bagi para pelatih sementara tiga prinsip terakhir lebih berkaitan dengan kasus-kasus khusus. Selanjutnya Jackie Hudson juga mengajukan sepuluh prinsip-prinsip umum konsep kinematika yang benar-benar mendasar. Menurutnya prinsip-prinsip biomekanika olahraga harus dapat dilihat secara visual oleh pelatih dan atlet agar dapat benar-benar berguna dalam meningkatkan performa. Hal yang menarik dari prinsip-prinsip yang diajukannya adalah menghindari terminologi yang terdengar sangat ilmiah dan teknis sehingga prinsip-prinsip biomekanika dapat lebih mudah dikomunikasikan dan digunakan. Usaha mendefinisikan prinsip-prinsip umum biomekanika olahraga kemudian dilakukan oleh Duane Knudson. Sembilan prinsip yang diajukannya serupa dengan upaya-upaya sebelumnya, tetapi ia menyusunnya dengan cara mengorganisasikan menjadi prinsip gerakan tubuh dan prinsip-prinsip gerak proyeksi. Seperti upaya yang dilakukan oleh Hudson, Knudson mencoba menggunakan terminologi yang menjembatani kesenjangan antara sains (teori) dan pelatihan (aplikasi) di lapangan melalui istilah-istilah yang lebih populer. Penggunaan istilah yang lebih populer, alih-alih kosataka ilmiah, dapat dipandang sebagai suatu kekhasan dalam prinsip-prinsip umum biomekanika kualitatif yang diajukan oleh Knudson tersebut.

Penggunaan istilah yang lebih populer membuat terminologi yang digunakan antara satu ilmuwan dengan ilmuwan biomekanika olahraga lainnya terlihat "kacau" dan tidak konsisten. Pada tabel tersebut terlihat perbedaan dalam penggunaan terminologi untuk konsep yang relatif sama antara satu ilmuwan dengan ilmuwan biomekanika lainnya. Di tempat lain, para pelatih kadang menggunakan istilah pribadi yang berbeda dengan teori atau prinsip biomekanika. Dalam hal ini 
prinsip-prinsip biomekanika kualitatif tampaknya masih menggunakan istilah yang beragam untuk konsep yang sama. Hal ini justru yang ingin dibahas oleh Knudson melalui pemaparan tiga teori aplikasi kualitatif biomekanikanya. la dengan jelas menunjukkan arah yang mungkin bisa dituju oleh teori yang berkaitan dengan aplikasi kualitatif biomekanika pada olahraga, yaitu bagaimana prinsip umum biomekanika dapat dipahami substansinya oleh para pelatih olahraga terlepas dari perbedaan istilah yang dipakai. Substansi inilah yang menjadi inti aplikasi kualitatif biomekanika pada olahraga. Isu mengenai variabilitas gerak dalam suatu performa olahraga, sebagaimana disinggung sebelumnya, akhirnya dapat diakomodasi dalam prinsip-prinsip umum ini.

Dari segi keilmuan, upaya menyusun prinsip-prinsip umum biomekanika kualitatif sejalan dengan aplikasi sport science. Dalam suatu diskusi mengenai konsep kunci sport science, David Bishop, seorang Associate Professor di Facolta di Scienze Motorie di Verona Italia, berpendapat jika sport science merupakan area keilmuan yang multidisiplin yang menaruh perhatian pada pemahaman dan peningkatan performa olahraga. Biomekanika merupakan salah satu area multidisiplin yang dimaksud. Pendapatnya yang lain adalah mengenai sport science yang berkaitan dengan menggunakan bukti-bukti terbaik yang tersedia pada waktu, lingkungan dan individu yang tepat untuk meningkatkan performa mereka. Selanjutnya sport science mengandalkan upaya yang dapat mengubah riset menjadi praktik keseharian (Haff, 2010). Hal ini tentu sangat sesuai dengan tujuan yang ingin dicapai dengan menetapkan prinsip-prinsip umum biomekanika kualitatif dalam olahraga. Meskipun sering terhadang persoalan validitas dan reliabilitas, prinsip-prinsip umum biomekanika olahraga kualitatif kiranya dapat diterima sebagai suatu upaya dalam menerapkan sport science melalui perannya sebagai penghubung antara teori dan aplikasi di lapangan.

Dalam mengembangkan prinsip-prinsip biomekanika kualitatif dibutuhkan kesepakatan yang jelas antara ilmuwan biomekanika dan komunitas pelatih mengenai apa yang dimaksud dengan aplikasi konsep atau prinsip-prinsip biomekanika. Sesuai saran Knudson (2007b), para ilmuwan biomekanika hendaknya bekerja bersama menjaga konsistensi terminologi literatur biomekanika terapan. Pada tingkat internasional upaya ini mungkin akan menghadapi banyak kendala, namun pada tingkat nasional para tenaga biomekanika dan pelatih dapat mengembangkan suatu prinsipproinsip umum biomekanika kualitatif olahraga untuk digunakan di negara masing-masing. Melalui langkah ini, analisis biomekanika diharapkan dapat lebih memberikan informasi yang lebih berarti.

\section{Simpulan}

Desakan untuk memanfaatkan apa yang disebut sebagai sport science semakin menguat dari waktu ke waktu. Bagi para pelaku olahraga baik pelatih, atlet dan aktor lainnya, performa terbaik merupakan suatu ultimate goal. Untuk itu mereka dituntut untuk dapat meningkatkan keterampilan gerak sekaligus mengurangi risiko cedera yang mungkin dialami atlet. Guna mencapai tujuan tersebut, analisis biomekanika olahraga dapat menjadi alat pendukung bagi para pelatih. Prinsip dan penelitian biomekanika olahraga seharusnya menjadi sumber pengetahuan utama bagi pelatih dalam melakukan analisis gerak olahraga. Masalahnya, hasil analisis biomekanika olahraga kadang tidak dapat digunakan dengan mudah. Hal ini tidak lepas dari analisis biomekanika olahraga sangat diwarnai oleh pendekatan kuantitatif melalui matematika dan fisika. Seiring waktu dan persoalan yang ditemui di lapangan, pendekatan biomekanika kualitatif semakin dinilai penting, terus berkembang dan bahkan mengakar sehingga menjadi bagian penting dalam menganalisis gerak dan memberikan masukan kepada atlet. Prinsip-prinsip biomekanika kualitatif dinilai dapat menjembatani antara teori dan aplikasi guna mendapatkan analisis biomekanika olahraga yang lebih bermakna. Pendekatan biomekanika kualitatif melalui prinsip-prinsip umum yang telah dibahas layak diterima sebagai suatu upaya menjadikan sport science lebih menyentuh praktik nyata di lapangan. Upaya ini tentunya selaras dengan penerapan sport science sebagai semangat yang dibawa dari kebangkitan olahraga nasional, khususnya setelah Asian Games 2018. 


\section{Ucapan terimakasih}

Naskah ini merupakan pengembangan dari makalah perkuliahan pada Program Studi IImu Keolahragaan Pascasarjana Universitas Negeri Yogyakarta. Hysa Ardiyanto mengucapkan terimakasih kepada Lembaga Pengelola Dana Pendidikan (LPDP) Kementerian Keuangan Republik Indonesia yang telah memberi dukungan pada studinya.

\section{Referensi}

Adina, F. F., Saichudin, S., \& Kinanti, R. G. (2017). Analisis gerak jump shoot terhadap tingkat keberhasilan point di tim bola basket unit kegiatan mahasiswa. Jurnal Sport Science, 7(1), 1525.

Anam, A. K., \& Hidayah, T. (2014). Analisis gerak tendangan depan pada ekstrakurikuler pencak silat. Journal of Sport Sciences and Fitness, 3(3), 19-24.

Arifin, Z. (2014). Analisis gerakan servis atas dalam permainan sepak takraw berdasarkan konsep biomekanika. Jurnal Pendidikan Olahraga, 3(1), 94-103.

Bartlett, R. (2007). Introduction to sports biomechanics: analysing human movement patterns (2nd ed.). Abingdon: Routledge.

Bartlett, R., Wheat, J., \& Robins, M. (2007). Is movement variability important for sports biomechanists? Sports Biomechanics, 6(2), 224-243. https://doi.org/10.1080/14763140701322994

Buekers, M., Ibáñez-Gijón, J., Morice, A. H. P., Rao, G., Mascret, N., Laurin, J., \& Montagne, G. (2016). Interdisciplinary research: a promising approach to investigate elite performance in sports. Quest, 1-14. https://doi.org/10.1080/00336297.2016.1152982

Haag, H., Grupe, O., \& Kirsch, A. (1992). Introduction. In H. Haag, O. Grupe, \& A. Kirsch (Eds.), Sport science in Germany an interdisciplinary anthology (pp. 1-6). Berlin: Springer.

Haff, G. G. (2010). Sport science. Strength and Conditioning Journal, 32(2), 33-45. https://doi.org/10.1519/SSC.0b013e3181d59c74

Hsieh, C., \& Knudson, D. (2017). Important learning factors in high- and low-achieving students in undergraduate biomechanics. Sports Biomechanics, 1-10. https://doi.org/10.1080/14763141.2017.1347194

Irianto, D. P. (2018, September 4). Kebangkitan olahraga. Kedaulatan Rakyat, p. 1.

Iskandar, I. (2013). Analisis gerakan passing bawah dalam permainan bola voli berdasarkan konsep biomekanika. Jurnal Pendidikan Olah Raga, 2(2), 150-162.

Jones, R. L. (2011). Introduction. In R. L. Jones, P. Potrac, C. Cushion, \& L. T. Ronglan (Eds.), The sociology of sports coaching (pp. 3-11). Taylor \& Francis e-Library.

Knudson, D. (2005). Evidence-based practice in kinesiology: the theory to practice gap revisited. Physical Educator, 62(4), 212-221. Retrieved from http://www.freepatentsonline.com/article/Physical-Educator/140997411.html

Knudson, D. (2007a). Fundamentals of biomechanics (2nd ed.). New York: Springer.

Knudson, D. (2007b). Qualitative biomechanical principles for application in coaching. Sports Biomechanics, 6(1), 109-118. https://doi.org/10.1080/14763140601062567

Knudson, D. (2009). Significant and meaningful effects in sports biomechanics research. Sports Biomechanics, 8(1), 96-104. https://doi.org/10.1080/14763140802629966

Knudson, D. (2013). Physics and biomechanics education research: Improving learning of biomechanical concepts. Proceedings of the 31st International Conference of the International Society of Biomechanics in Sports, 77-76.

Knudson, D. (2017). Confidence crisis of results in biomechanics research. Sports Biomechanics, 1-9. 
https://doi.org/10.1080/14763141.2016.1246603

Knudson, D., \& Morrison, C. (2002). Qualitative analysis of human movement (2nd ed.). Champaign, IL: Human Kinetics.

Kristiyanto, A. (2017, July 6). Kebangkitan ristek olahraga. Solopos, p. 4. Retrieved from https://epaper.solopos.com/06072017-2/0004-904/

Kurniawan, F. (2015). Analisis secara biomekanika terhadap kekerapan kesalahan pada teknik gerak serang dalam pertandingan anggar. Jurnal Olahraga Prestasi, 11(1), 73-90.

McGinnis, P. M. (2013). Biomechanics of sport and exercise (3rd ed.). Champaign, IL: Human Kinetics. Retrieved from http://books.google.co.uk/books/about/Biomechanics_of_Sport_and_Exercise.html?id=awmp rqGqFo4C\&pgis=1

Pemerintah Republik Indonesia. (2005). Undang-Undang Republik Indonesia nomor 3 tahun 2005 tentang sistem keolahragaan nasional.

Rismayanthi, C., \& Alim, A. (2011). Analisis biomekanik teknik servis pada atlet senior DIY. Jurnal Penelitian Saintek, 16(1), 73-86.

Tighe, A., \& Kenny, I. C. (2015). A qualitative biomechanical analysis of the punt kick in gaelic football, comparing dominant and non dominant kicking legs. In GAA Games Development Conference. Dublin.

van Wilgen, C. P., \& Verhagen, E. A. L. M. (2012). A qualitative study on overuse injuries: The beliefs of athletes and coaches. Journal of Science and Medicine in Sport, 15(2), 116-121. https://doi.org/10.1016/j.jsams.2011.11.253

Widiyanto, W., \& Hariono, A. (2014). Analisis gerak teknik tendangan depan atlet pencak silat PPLM DIY (sebuah kajian biomekanika olahraga). In S. Sukadiyanto \& S. Suharjana (Eds.), Seminar Nasional Olahraga (pp. 26-44). Yogyakarta. Retrieved from http://staff.uny.ac.id/sites/default/files/penelitian/awan-hariono-mor/analisis-gerak-tekniktendangan-depan-atlet-pencak-silat-pplm-diy-sebuah-kajian-biomekanika-olahraga.pdf

Wijaya, A. (2017). Analisis gerak keterampilan servis dalam permainan bulutangkis (suatu tinjauan anatomi, fisiologi, dan biomekanika). Indonesia Performance Journal, 1(2), 106-111. Retrieved from http://journal2.um.ac.id/index.php/jko/article/download/2466/1486 